\title{
Carbon dynamics of Deep Bay, eastern Pearl River Estuary, China. I: A mass balance budget and implications for shorebird conservation
}

\author{
M. S. Li, S. Y. Lee* \\ The Swire Institute of Marine Science and Department of Ecology \& Biodiversity, The University of Hong Kong, \\ Pokfulam Road, Hong Kong
}

\begin{abstract}
Deep Bay is a shallow embayment $\left(112 \mathrm{~km}^{2}\right)$ in the eastern Pearl River Estuary, China, and comprises 4 major wetland components: (1) a shallow brackish water body of $2.9 \mathrm{~m}$ average depth, (2) 2700 ha of intertidal mudflat, (3) 200 ha of tidal mangroves and (4) 300 ha of traditional tidal aquaculture ponds excavated in the mid-to-high intertidal region. A carbon budget is proposed for Deep Bay based on published information on the 4 major landscape components. Despite the usual emphasis placed on the role of mangroves as net carbon exporters in support of consumer (such as shorebird) populations, the carbon budget suggests that about $50 \%$ of all carbon available in Deep Bay originates from anthropogenic input from rapidly urbanising, as well as agricultural, areas in the local catchments. Mangrove production only contributes about $1.8 \%$ of the total carbon available in Deep Bay. Calculations based on the basal metabolic demands of the bird assemblage in winter suggest that the Deep Bay mudflats are close to carrying capacity. The annual carbon requirements of the shorebirds and availability (as demonstrated by the supply/demand ratio for the curlew) are lowest in the winter months, when bird numbers are large but production low. Considering the shorebird assemblage foraging on the mudflat, the total carbon consumption in January 1994 amounted to $16.9 \mathrm{t}$, while the carbon production during the same period was $27.8 \mathrm{t}$. These figures suggest that Deep Bay is near carrying capacity unless $>50 \%$ of the invertebrate resources are made available to the birds. The results of this study also argue that organic enrichment in Deep Bay, which has usually been regarded as a 'pollutant', forms the basis of the major beneficial use of carbon (shorebird conservation), although further enrichment may result in negative impacts. This study highlights the importance of incorporating human influences into the study of the structure and function of ecosystems in urban settings.
\end{abstract}

KEY WORDS: Benthos - Hong Kong - Mangroves - Mudflat Organic pollution - Carbon budget Tidal ponds - Bird conservation

\section{INTRODUCTION}

Classic studies on mangrove-based food chains in Florida (e.g. Heald 1971, Odum 1971, Odum \& Heald 1972, 1975, Odum et al. 1982) suggested that most mangrove litter was flushed from fringing and riverine forests by tidal action. Initial processing of litter

\footnotetext{
- Addressee for correspondence. Present address: School of Applied Science, Faculty of Environmental Sciences, Griffith University Gold Coast, PMB 50, Gold Coast Mail Centre, Queensland 9726. Australia. E-mail: joe.lee@gu.edu.au
}

occurred in subtidal regions where leaf material was rapidly fragmented through the grazing action of crabs and amphipods (Heald 1971), followed by decomposition through fungal and bacterial activities (Heald 1971, Fell et al. 1975, Cundell et al. 1979). These detrital particles were then utilised by a variety of detritivores (Odum \& Heald 1972, 1975). Tidal flushing was identified as the major agent determining the extent of export of mangrove organic matter (Twilley 1985, Twilley et al. 1986). The geomorphologic characteristics of a site have strong influences over the degree of export (Odum et al. 1979). 
The Florida model has been challenged by new findings from Indo-Pacific systems in the last decade. Robertson (1986) first demonstrated that leaf-consuming crabs Sesarma spp. played a significant role in litter turnover of mangrove ecosystems in the Indo-West Pacific, a phenomenon later supported by other studies. For example, Lee (1989b) reported that Sesarminae crabs were capable of consuming $>57 \%$ of the daily leaf litter during their active season in a high intertidal Kandelia candel mangrove stand, and Emmerson \& McGwynne (1992) estimated $44 \%$ consumption in a South African forest. Such in situ consumption by crabs reduces tidal export and may also initiate further processing of mangrove-derived organic carbon by way of coprophagous food chains based on crab faeces (Lee 1997).

Estimates of organic carbon export from intertidal wetlands range from $45 \%$ (Teal 1962, Axelrad et al. 1976, Twilley 1985) to less than 1\% (Heinle \& Flemer 1976) of their net production, while some intertidal wetlands may even import organic carbon (e.g. Woodwell et al. 1977, Lee 1990a, Asjes \& Dankers 1994). Some authors consider exported mangrove particulate matter to be highly refractory and to have little influence on coastal food chains (Robertson et al. 1992). Recent application of carbon isotope techniques in subtropical and tropical mangrove systems (e.g. Rodelli et al. 1984, Rezende et al. 1990, Hemminga et al. 1994) has indicated that the number of consumers in tropical coastal regions adjacent to mangrove forests that are dependent on mangrove carbon is smaller than that suggested by the classic paradigm. The influence, if significant, is often of limited spatial extent (e.g. Moran et al. 1991). These findings have highlighted the need for a reassessment of the role of mangroves in nearshore trophodynamics, and the need to incorporate local as well as biogeographic variations in ecosystem function. Mangrove outwelling has recently been reviewed by Lee (1995a). After examining 26 post1975 reports on mangrove material exchange with nearshore systems, this author concluded that, while most mangroves tend to export, the magnitude and direction of exchange depend on the chemical species and that export is usually smaller than previously assumed in most systems

Another recent development that has largely been ignored in mangrove ecosystem studies is the influence of anthropogenic changes on ecosystem function. Mangroves are globally under threat from urban development and consumptive utilisation (e.g. intensive prawn culture), resulting in the loss of about $1 \%$ of world mangrove areas every year (Hatcher et al. 1989). While human disturbance undoubtedly causes largescale mangrove destruction, the impact of human activities and interference on the trophodynamics of mangrove-dominated coastal areas is yet to be documented. While classic arguments (e.g. that mangroves provide the dominant carbon source to tropical offshore fisheries and inshore consumers) are still being used to support mangrove conservation, the actual value of mangroves in human-impacted coastal food chains requires some reassessment.

Mangroves and their associated habitats, e.g. intertidal mudflats, often provide roosting and breeding areas for shorebirds, which are usually the top consumers of the system. In the eastern Pearl River Estuary in southern China, over 320 species of birds have been recorded from the mangrove-dominated Deep Bay wetlands, of which 22 are recognised as rare and endangered (Young 1995). Only around $16 \%$ of the total bird species found here are residents, with most other species being migrants or winter visitors (Young \& Melville 1993). Deep Bay lies between China and Hong Kong and comprises the Futian (110 ha) and Mai Po (380 ha) wetlands, respectively, in the 2 political entities. Areas around Deep Bay are amongst the most rapidly urbanising areas in the Pearl River estuary. In the last $10 \mathrm{yr}$, the Mai Po-Futian wetlands of Deep Bay have been the topic of extensive scientific research both in Hong Kong and China, mainly because this wetland complex supports an increasingly large number of birds. The Hong Kong Bird Watching Society has been conducting mid-winter bird counts in Deep Bay each year since 1979 (except 1980). Data from the counts are published in the Hong Kong Bird Report annually, the latest number being a total of $>68000$ birds being counted in various parts of Deep Bay in 1996. Lee (1989a, b, 1990a, b, c, 1991, 1992) and Anderson (1994) have studied the various aspects of the production ecology of mangroves of Mai Po. Li (1993, 1997) investigated mangrove ecology on the Futian side of Deep Bay. A number of studies (Chan 1989, Yang 1996, McChesney 1997) reported on various aspects of benthic invertebrate production and consumption by birds on the mudflats in Deep Bay.

This paper, a synthesis based on the above and other works, aims at profiling the carbon dynamics from information collected from the various habitats in the bay. The carbon budgets of the main landscape components are briefly discussed below. The contribution from these components to the carbon available on the mudflats in Deep Bay will then be calculated based on known or estimated rates of exchange between these components and Deep Bay. The relative importance of anthropogenic versus natural sources of food supplies available to the shorebird populations supported by the Deep Bay wetlands is assessed, with a discussion of the implications of these findings for shorebird conservation on the mudflats. 


\section{STUDY SITE}

Deep Bay for Shenzhen Bay, as it is called in China; 22.41 to $22.53^{\circ} \mathrm{N}, 113.88$ to $114.00^{\circ} \mathrm{E}$ ) is situated to the northwest of Hong Kong, lying between Hong Kong and soutb China. It is approximately $17.5 \mathrm{~km}$ long and between 4.2 and $10 \mathrm{~km}$ wide (Liu et al. 1988), covering an area of $112 \mathrm{~km}^{2}$, and opens directly to the Pearl River Estuary to the southwest (Fig. 1). The 2 main local rivers discharging into Deep Bay are the Shenzhen River, forming the border, and the Shan Pui River, draining the largest agricultural area of Hong Kong. The head of Deep Bay receives effluent from the Shenzhen River, which flows through the Shenzhen Special Economic Zone in China, a metropolitan area with extremely rapid economic growth in the past 10 yr. Both sides of the Shenzhen River mouth are fringed with mangroves extending from east to west. The northern component is an $11 \mathrm{~km}$ long continuous mangrove belt (20 to $200 \mathrm{~m}$ wide) which was designated as the Futian Mangrove-Bird Nature Reserve by China in 1984. On the southern shores of Deep Bay lies the Mai Po Marshes Nature Reserve, designated in 1976 by the then Hong Kong government as an SSSI (Site of Special Scientific Interest) and declared as a Ramsar site in 1995. Both the Shenzhen and Shan Pui Rivers are heavily enriched with high organic loadings of domestic wastewater, especially from livestock wastes in the Shan Pui River catchment. The average water depth of the bay is only $2.9 \mathrm{~m}$ and, consequently, a large expanse of intertidal mudflats (2700 ha) is exposed during low tide. An irregular semidiurnal tide dominates this bay with a maximum tidal range of about $2.8 \mathrm{~m}$. The annual average temperature (in 1995 ) is $22.8^{\circ} \mathrm{C}$, with an average maximum of $31.2^{\circ} \mathrm{C}$ (June) and an average minimum of $13.5^{\circ} \mathrm{C}$ (February). The annual precipitation totals $2754.4 \mathrm{~mm}$, with the rainy season lasting from April to September (Royal Observatory, Hong Kong 1995).

The ecological significance of the Deep Bay wetlands primarily lies in its capacity to support large populations of wintering and migrant birds. The total number of birds recorded in the most recent survey in January 1996 amounted to $>68000$ individuals. In view of the immense conservation significance of the Deep
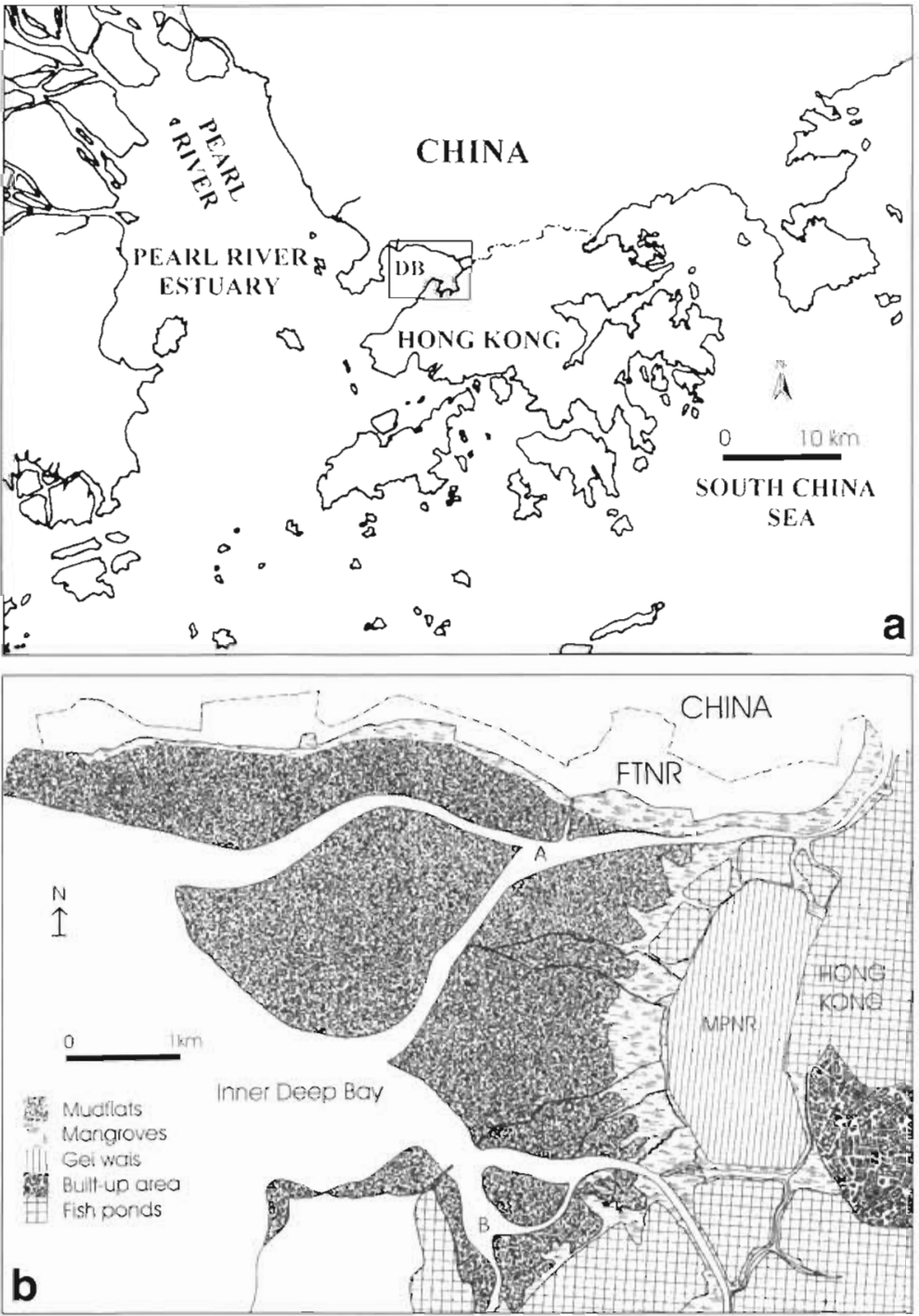

Fig. 1. (a) Geographic position of Deep Bay (DB) in the Pearl River estuary; box encloses the area of study. (b) Deep Bay study area. FTNR: Futian Mangrove-Bird Nature Reserve; MPNR: Mai Po Marshes Nature Reserve; A: Shenzhen River; B: Shan Pui River

Bay wetlands, the Hong Kong Government declared the southern half of the Deep Bay wetlands as Hong Kong's first and only Ramsar site in September 1995. The site comprises an area of 1500 ha of intertidal mudflat, mangrove forest, tidal aquaculture ponds and freshwater fish ponds in the northwestern extreme of Hong Kong (Fig. 1).

The Deep Bay wetlands comprise 4 different major habitat components: (1) large tidal aquaculture ponds (gei wai) in Mai Po, (2) tidal mangroves in Mai Po and Futian, (3) the intertidal mudflats, and (4) the water body. The characteristics and data available on the carbon dynamics of the 4 habitat types are briefly described below. 


\section{Mai Po gei wais}

Gei wais (traditional tidal prawn farming ponds) in Mai Po were originally excavated from the mangrove in the 1940s (Irving \& Morton 1988). Each pond is a rectangular impoundment with drainage channels and remnant mangrove stands dominated by Kandelia candel. There are now 270 ha of gei wais in operation, each with an average area of 9 to 10 ha. Each gei wai has a sluice gate $(1.8 \times 1.3 \mathrm{~m})$ situated in a channel leading through the tidal mangroves and communicating with Deep Bay. The sluice gate allows water level management of the gei wai to be controlled. With decline in use and maintenance, the gei wais have been, of late, invaded by a more typically freshwater wetland species, Phragmites communis (Lee 1990b).

\section{Tidal mangroves}

Some 90 ha of tidal mangroves occur at Mai Po, measuring $3 \mathrm{~km}$ long and 200 to $500 \mathrm{~m}$ wide. The dominant species are Kandelia candel, Aegiceras corniculatum and Avicennia marina. Mangrove trees are, on average, $5 \mathrm{~m}$ tall but can be as high as $8 \mathrm{~m}$. Unlike Mai Po, the Futian mangroves are narrower in width (20 to $200 \mathrm{~m}$ ) and denser. The mangrove area at Futian approximates 111 ha. Here $A$. corniculatum forms relatively pure stands. The average height of this mangrove is $4.5 \mathrm{~m}$, with no obvious vertical stratification. No gei wais exist but some unvegetated fish ponds occur in the back of the mangroves. Together with the forest at Mai Po, the Deep Bay mangroves represent the sixth most extensive mangrove forest along the south China coast (Li \& Lee 1997). Entry to both mangroves is restricted because of their location in frontier areas.

\section{Intertidal mudflat and overlying water}

About 2700 ha of mudflats are exposed in inner Deep Bay during low tide. These mudflats host numerous benthic animals, which form the trophic basis for a large number of shorebirds every winter. More birds concentrate on the lower reach of the mudflat than on the upper reach. The mean water volume in Deep Bay is estimated at $3.3 \times 10^{8} \mathrm{~m}^{3}$ (Han et al. 1988) with high turbidity (suspended solids averaged at $31.1 \mathrm{mg} \mathrm{l}^{-1}$; Environmental Protection Department [EPD] 1994). Salinity falls to between 5 and $15^{\circ}$ in the wet season but increases to $28-32 \%$ in the dry season, according to the degree of freshwater influx from both the local catchment and the Pearl River, which has a peak discharge of $1800 \times 10^{6} \mathrm{~m}^{3} \mathrm{~d}^{-1}$ (Broom \& Ng 1996).

\section{MATERIALS AND METHODS}

A carbon budget requires information on the standing stock of the main ecosystem constituents, rates of net primary production, rates of production and consumption by the main heterotrophs, storage and export. The basic information required for the calculation of these parameters is derived from various sources of published data on Mai Po and Futian (Table 1). Important fluxes and storage values are identified and quantified, as much as possible, for each of the habitat components in the bay. It should be noted, however, that this study aims to provide an overview of the pattern of carbon dynamics rather than details of the individual processes driving the pattern. Readers are referred to the respective studies for a more in-depth treatment of the component processes. The assumptions and limitations of the calculations reported upon are discussed where appropriate.

Mangroves. Some structural differences exist between mangroves in Mai Po and Futian. The mangroves in Futian are much denser than in Mai Po (11043 vs 5650 stems ha ${ }^{-1}$ ) and have a higher proportion of Aegiceras corniculatum (62.6 vs $41.7 \%$ ) and Kandelia candel (31.1 vs $24.3 \%$ ) but a much lower Avicennia marina ( 6.3 vs $34.1 \%$ ) abundance. The biomass, NAPP (net aboveground primary production), and litter production of pure $K$. candel/A. marina forests in Mai Po and a pure $A$. corniculatum stand in Futian have been reported respectively by Anderson (1994) and Li (1993). Consumption by crabs and storage and export of the litter of pure $K$. candel and $A$. marina stands, as well as herbivory on $K$. candel and $A$. marina leaves have been documented (Lee 1989a, Anderson 1994, Kwok 1995), but are not available for A. corniculatum. Since the $\mathrm{C} / \mathrm{N}$ ratio of $A$. corniculatum leaves is close to that of $K$. candel (Li 1993), the rates of herbivory, consumption, storage and export for $K$. candel have been used to allow a rough estimate for $A$. corniculatum. Li (1993) and Li et al. (in press) have measured the carbon contents of different tissues including litter components, for the 3 species. To calculate the carbon budget of the whole mangroves (generally the mixed forest), the extensive mangrove survey data for Mai Po (Peking University 1995) and in Futian (Chen et al. 1996) were used to convert the above values obtained from pure stands into the equivalents for the actual forests. These forest values were obtained by dividing the density of $K$. candel/A. corniculatum and A. marina in the Mai Po and Futian forests by their respective density values in the pure stands (Table 2). The net amount of organic carbon exported from these forests was then estimated based on the areal extent of the trees and the production and export rates documented in Li (1993) and Anderson (1994) 
Table 1 Data sources for information used in this study. NAPP = net aboveground primary production; TOC = total organic carbon: $\mathrm{POC}=$ particulate organic carbon $; \mathrm{BOD}_{5}=$ biochemical oxygen demand

\begin{tabular}{|c|c|c|}
\hline Habitat & Parameter & Source \\
\hline \multirow[t]{6}{*}{ Mangroves (Mai Po and Futian) } & Tree density & $\begin{array}{l}\text { Peking University (1995), Anderson (1994), } \\
\text { Chen et al. (1996), Li (1993) }\end{array}$ \\
\hline & NAPP, litter fall rate & Anderson (1994), Li (1993), Li et al. (in press) \\
\hline & Storage, consumption, export & Anderson $(1994)$ \\
\hline & Herbivory & Anderson (1994), Anderson \& Lee $\{1995$ \} \\
\hline & TOC content & Li (1993), Lee $(1990 a, 1993)$ \\
\hline & Benthic algal biomass & Anderson $(1994)$ \\
\hline \multirow[t]{6}{*}{ Gei wais } & $\begin{array}{l}\text { NAPP of Kandelia candel and } \\
\text { Phragmites communis }\end{array}$ & Lee $(1990 \mathrm{a}, \mathrm{b})$ \\
\hline & $\begin{array}{l}\text { Benthic algal biomass and phyto- } \\
\text { planktonic productivity }\end{array}$ & Lee (1990a) \\
\hline & Herbivory & Lee $(1990 \mathrm{c})$ \\
\hline & Litter fall rate and turnover & Lee $(1989 a, b)$ \\
\hline & Sedimentation & Lee $(1990 a)$ \\
\hline & Harvest of prawns and fish & Cha et al. (1996) \\
\hline \multirow[t]{5}{*}{ Mudflats } & Benthic algal biomass & Anderson (1994), Yang (1996) \\
\hline & $\begin{array}{l}\text { Biomass and production of benthic } \\
\text { invertebrates }\end{array}$ & McChesney (1996) \\
\hline & Mudskipper bromass and catch & Chan (1989), Young \& Melville (1993) \\
\hline & Bird count & Hong Kong Bird Watching Society (1995) \\
\hline & Curlew's dietary demand & Melville et al. (1995) \\
\hline \multirow[t]{3}{*}{ Water body } & Phytoplanktonic productivity & Huang et al. $(1996)$ \\
\hline & $P O C$ content and equation & $\begin{array}{l}\text { Chen et al. (1990), Environmental Protec- } \\
\text { tion Department (EPD) (1995) }\end{array}$ \\
\hline & Volume and turnover rate & Han et al. (1988) \\
\hline \multirow[t]{2}{*}{ Allochthonous input } & $\mathrm{BOD}_{5}$ to TOC equation & Xie $(1989)$ \\
\hline & Water quality data & EPD (1995), Peking University (1995) \\
\hline
\end{tabular}

Table 2. The density-based conversion factors used to convert the data from pure mangrove stands to the actual mangrove forests in Mai Po and Futian

\begin{tabular}{|lcccc|}
\hline Species & $\begin{array}{c}\text { Density in } \\
\text { pure stands } \\
\text { (stems ha }\end{array}$ & $\begin{array}{c}\text { Density in actual mangroves } \\
\text { Mai Po }\end{array}$ & $\begin{array}{c}\text { Futian } \\
\text { (stems ha }{ }^{-1} \text { ) }\end{array}$ & $\begin{array}{c}\text { Conversion factors } \\
\text { Mai Po }\end{array}$ \\
\hline Kandelia candel & 11170 & 1370 & 3429 & 0.1226 \\
Avicennia marina & 5450 & 1926 & 700 & 0.3534 \\
Aegiceras corniculatum & 15657 & 2354 & 6914 & 0.1503 \\
Total & & 5650 & 11043 & 0.1284 \\
\end{tabular}

Gei wais. The 24 prawn ponds (gei wai) in Mai Po support extensive stands of mangroves (17.5 ha) and reed (46 ha) in the central islands (Cha et al. 1996). The major primary producers in the ponds are Kandelia candel, Phragmites communis, macroalgae and phytoplankton, and consumers in the stands are mainly sesarmine crabs. All ponds are operated in the traditional manner, i.e. with no fertilisation or artificial stocking of the cultured species. The total carbon production, consumption and exchange with Deep Bay were calculated with the values collected from one of the ponds (Lee 1990a) multiplied by the respective areas of each compartment. Overall rates of herbivory loss, detritus export and consumption by crabs could then be estimated collectively for the gei wais. Harvest from the gei wais (mainly for the penaeid Metapenaeus ensis and fish Sparus latus and Mugil cephalus) was estimated from the mean values of the 7 ponds managed by World Wide Fund for Nature Hong Kong (Cha et al. 1996). Carbon content was not determined for prawns and fish and a TOC (total organic carbon) value of $15 \%$ of the wet weight was assumed. 
Mudflats. Benthic microalgae are the main primary producers on the mudflat. Yang (1996) studied the dynamics of the microalgal community on the intertidal mudflat over 18 mo and recorded consistently higher ( 1 to $3.5 \times$ ) phaeopigment concentrations over those of chlorophyll a. This pattern probably suggests a high turnover rate of the microalgal assemblage. Assuming that annual production is 3 times as large as the peak benthic algal biomass, the carbon production can be estimated with an average organic carbon content of $35 \%$ (Lee 1990a). Carbon:chlorophyll a ratios of 62 and $42 \%$ (Valiela 1995) were used, respectively, for the conversion to biomass values for the phytoplankton and sediment microalgae from chlorophyll a values (Liu et al. 1988, Chiu 1992). Invertebrate production on the mudflat was obtained from McChesney (1997), who estimated production following the method of Crisp (1984).

Water body. Deep Bay is the only narrow-mouth inlet in the Pearl River Estuary, which is the outlet of the largest river in south China, the Pearl River. Tidal exchange between Deep Bay and the Pearl River estuary is effected through tidal currents twice a day. The semi-residence time of Deep Bay water was documented to be nearly $4 \mathrm{~d}$ (Han et al. 1988); hence, the daily water exchange between Deep Bay and the estuary was about $4.125 \times 10^{7} \mathrm{~m}^{3}$. Chen et al. (1990) reported that the POC (particulate organic carbon) concentration in this estuarine water body had an average of $292.7 \mathrm{\mu g} \mathrm{l}^{-1}$ (average of 22 measurement points) and this was determined by the salinity and $p H$ of the water. Since this relation is rarely adopted for predicting POC concentrations, an alternative method of estimation was used. The POC content of inner and outer Deep Bay was calculated using the annual average suspended solids level reported in EPD (1995), and with an assumed organic carbon content of the suspended solids at $1.5 \%$. An organic content value lower than those recorded from Shan Pui River and Shenzhen River is adopted in view of the predominantly inorganic nature of the suspended matter load in the Pearl River. The average POC value of Deep Bay was used to calculate the daily carbon flux to the estuary carried by tidal water. Carbon production by phytoplankton in the water column was calculated based on values measured by Huang et al. (1996) in the Pearl River estuary.

Anthropogenic input. The equation $\mathrm{TOC}=$ $1.6\left(\mathrm{BOD}_{5}\right)+21.8(\mathrm{r}=0.97, \mathrm{n}=18)$ (Xie 1989), where $\mathrm{BOD}_{5}$ is the biological oxygen demand, was employed to estimate the anthropogenic carbon input into Deep Bay through the heavily polluted Shenzhen and Shan Pui Rivers. $\mathrm{BOD}_{5}$ values of the 2 rivers were from $\mathrm{EPD}$ (1995) and Peking University (1995). Due to the expected lower levels of diffused input and the gen- eral lack of detailed information, other potential carbon sources, such as rainwater runoff from the hinterlands were excluded in this investigation. TOC from the 2 river sources was computed from the $\mathrm{BOD}_{5}$ values over the course of a year and all TOC was assumed to be exported from the rivers into Deep Bay. This is probably an overestimation but there is to date no actual measurement of the percentage of the TOC retained by the 2 rivers.

Bird utilisation of the carbon source. At all times, only a fraction of the benthos is available to the birds. The extent of utilisation of the benthos by birds depends on both accessibility of the benthos and energetic profitability for the birds. Animals that burrow deeper than the birds can reach or exhibit active avoidance behaviour in the presence of predators are frequently inaccessible. Those with too large a size to be ingested or that are too small to be energetically profitable are usually not chosen by the birds. Of the birds regularly using the Deep Bay mudflat, only curlew have bills long enough to be capable of harvesting benthos to a depth of $12 \mathrm{~cm}$ (Melville \& Morton 1983, McChesney 1996), and they are observed to forage mostly on the mudflats. The case of the curlew was therefore used to demonstrate the level of resources available to birds in Deep Bay. The number of curlew for each of the months of 1994 was obtained from Hong Kong Bird Watching Society (1995), The carbon requirement of the curlew population was then estimated following equations relating basal metabolic rate and body biomass (Miere et al. 1994) and with a knowledge of the number of individuals on the mudflat. We are aware of the differences between field and basal metabolic rate (Pienkowski et al. 1984, Bryant \& Tatner 1991, Koteja 1991) but, as field rates are generally unavailable for the local species, the calculation here is based on basal metabolic rates estimated from body mass. The capacity of the mudflats to support the curlew population was then evaluated by calculating a supply to demand ratio (S/R) for the various months based on the total carbon requirement of the population and the biomass available on the mudflat at various times.

A second approach was adopted for estimating the capacity of Deep Bay to support wintering shorebird populations. The numbers of individuals of the major species of birds recorded in the mid-winter count conducted by the Hong Kong Bird Watching Society in January 1994 were used to calculate the carbon. requirements of the bird assemblage in a peak winter migration period. The total carbon requirements of the birds were estimated following the same approach as in the curlew calculation, i.e. based on published data of bird body weight and basal metabolic rate. The requirement was then compared with the amount of 
carbon available to the birds during the same period as an indication of the carrying capacity of the Deep Bay wetlands.

\section{RESULTS}

\section{Mangrove forests}

Generally, the production figures in Futian are higher than those in Mai Po, owing to its larger area (111 vs 90 ha) and higher tree density (11043 vs 5650 stems ha ${ }^{-1}$ ) (Table 3). Aegiceras corniculatum contributed most to the net aboveground primary productivity (NAPP), while Avicennia marina ranked last in both mangrove areas. The litter/production ratio was close to 1 for A. marina, but much lower for $A$. corniculatum and Kandelia candel, indicating that these 2 species were accumulating carbon in the community. Most litter types (leaves, twigs and small branches) probably decompose and recycle within 1 yr (Lee 1989a, b, Gong \& Ong 1990). Lee (1989a) and Kwok (1995) showed that the sesarmine crabs (mainly Perisesarma spp. and Parasesarma spp.) which are abundant in the mangroves played an important role in mangrove litter turnover. Calculations based on the density figures and the consumption rate of the crabs suggest that crabs consume 34.2 and $23.5 \%$ of the litter production in the Mai Po and Futian mangroves, respectively.

Herbivory is another pathway of energy transfer apart from detritivory. Herbivory rate (7.8\% of NAPP) of Avicennia marina is higher than that of Kandelia candel ( $4.0 \%$ of NAPP), probably due to the lower C/N ratio but higher toughness of the latter species. A recent phenomenon is that $A$. marina in the Deep Bay mangrove experiences intense herbivory almost every summer such that within 3 mo most trees are defoliated by a lepidopteran larva (Anderson \& Lee 1995), but this is excluded from the present carbon budget calculation because of its transient nature. Grazing loss on benthic algae was not determined in these mangrove areas but is expected to be high. Benthic algal production was 2.5 and 3.6 t yr $^{-1}$, respectively, in Mai Po and Futian, accounting for only 0.9 and $0.5 \%$ of the total NPP inet primary production) in the mangroves. A. marina usually has a more open canopy than the other 2 species in this forest; higher abundance of $A$. marina in the Mai Po mangrove allows more light penetration to the stand, thus leading to a relatively higher algal production than in Futian. Lee (1990a) found that production predictions based on benthic algal biomass underestimated net production by $12 \%$; the above values may, therefore, be lower than the real production. Assuming that all benthic algal production was exported from mangroves, the carbon export was estimated to be 150.5 (50.4\% of NAPP) and $440.3 \mathrm{t} \mathrm{yr}^{-1}$ (56.6\% of NAPP) for Mai Po and Futian mangroves. The total export from mangroves amounted to $590.7 \mathrm{t} \mathrm{C} \mathrm{yr}^{-1}$, which may be an important food source for the secondary producers in Deep Bay.

\section{Gei wais}

Gei wais in Mai Po comprise a raised zone of mangrove stands surrounded by a shallow canal (usually $<1 \mathrm{~m})$. These mangroves are rarely inundated $(<10 \%$

Table 3. Carbon budget of mangroves in Mai Po and Futian. All values are in $\mathrm{C} C \mathrm{yr}^{-1}$. NAPP $=$ net above-ground primary production; NPP = net primary production

\begin{tabular}{|c|c|c|c|c|c|c|c|}
\hline Mangrove & NAPP(NPP) & Herbivory & $\begin{array}{l}\text { Litter } \\
\text { fall }\end{array}$ & $\begin{array}{l}\text { Storage de- } \\
\text { composition }\end{array}$ & $\begin{array}{l}\text { In situ con- } \\
\text { sumption }\end{array}$ & $\begin{array}{l}\text { Crab litter } \\
\text { consumption }\end{array}$ & Export \\
\hline \multicolumn{8}{|l|}{ Mai Po } \\
\hline Kandelia candel & 90.0 & 3.6 & 76.8 & 5.7 & 0.6 & 13.7 & 56.9 \\
\hline Aegiceras corniculatum & 126.9 & 4.2 & 69.9 & 6.9 & 0.8 & 16.7 & 69.4 \\
\hline Avicennia marina & 79.2 & 6.2 & 71.8 & 5.3 & 0.6 & 44.4 & 21.7 \\
\hline Benthic algae & 2.5 & & & & & & 2.5 \\
\hline Sub-total & 298.6 & 14.0 & 218.5 & 17.9 & 2.0 & 74.8 & 150.5 \\
\hline \multicolumn{8}{|l|}{ Futian } \\
\hline Kandelia candel & 279.7 & 11.1 & 237.6 & 17.5 & 2.0 & 42.3 & 175.7 \\
\hline Aegiceras corniculatum & 459.5 & 15.2 & 252.6 & 25.1 & 2.8 & 60.5 & 251.3 \\
\hline Avicennia marina & 35.5 & 2.8 & 32.3 & 2.4 & 0.3 & 19.9 & 9.7 \\
\hline Benthic algae & 3.6 & & & & 3.6 & & \\
\hline Sub-total & 778.3 & 29.1 & 522.4 & 45.0 & 5.1 & 122.7 & 440.3 \\
\hline Total & 1077.0 & 43.1 & 740.9 & 62.8 & 7.1 & 197.5 & 590.7 \\
\hline
\end{tabular}


time) by tidal water (Lee 1990a). Impoundment and reduced tidal influence have resulted in a gradual transition to a more freshwater-wetland habitat, as is reflected by the spread of the reed Phragmites communis. The main producers, Kandelia candel and P. communis, contributed more than $95 \%$ of the total production in gei wais (Table 4). The macroalgae community was dominated by the chlorophyte Enteromorpha crinata and peak biomass was reached in late April (Lee 1990a), with an annual carbon production of

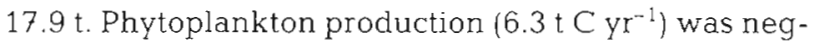
ligible because of the high turbidity in the tidal water and frequent cropping through tidal water exchange. Unlike in tidal mangroves, in gei weis almost all vascular plant litter was decomposed or consumed in situ, resulting in little export to and out of the ponds (Table 4). The total carbon export to the ponds was $24.6 \mathrm{t} \mathrm{yr}^{-1}$, of which $98 \%$ was from non-vascular plants. Mangrovcs (or reeds) are unlikely to provide significant amounts of food for the cultured species in the ponds as expected. The water-column consumers (prawns and fish) have to derive their carbon from allochthonous sources. The tidal water from Deep Bay compensated for the carbon deficit in the ponds by carrying in $988.4 \mathrm{t}$ each year and this becomes the major carbon source in the water column. Lee (1990a) reported an extremely high sedimentation rate of $1.7 \mathrm{~cm}$ $\mathrm{yr}^{-1}$ inside the ponds and this land-building process through accretion and litter accumulation seems to pose a problem to the prawn farming practice. Annual prawn and fish production in Mai Po gei wais were estimated to be 5.0 and $8.1 \mathrm{t}$, equivalent to 0.8 and $1.2 \mathrm{t}$ $C$, respectively. The average prawn harvest from gei wais has declined significantly in the last $6 \mathrm{yr}$, and this decline may be attributed to the abundance of predatory fish in the gei wais and dwindling larval abundance due to increasing water pollution in Deep Bay (Cha et al. 1996). This reduction, together with commercial harvest, decreases the food available for birds when the intertidal mudflats are inaccessible as feeding grounds during high tides.

\section{Mudflats}

The primary production of microalgae (dominated by the diatom Nitzchia palea) on the mudflat was estimated to be $1462.2 \mathrm{t} \mathrm{C} \mathrm{yr}^{-1}$ (Table 5). Although this may be an underestimate, it is more than 5 times higher than figures in the mangrove stands. Secondary production on the mudflat was assessed separately for 3 groups of organisms: crabs (mainly Macropthalmus spp.), other invertebrates (including gastropods, bivalves, polychaetes and oligochaetes) and mudskippers. Crabs on the mudflat are less abundant than in the mangroves (dominated by sesarmines), and the upper mudflats (dominated by $U_{c a}$ spp.) adjoining mangroves usually have more crab burrows than the lower mudflats (McChesney 1997). Crab production based on the density values was estimated to be $40.7 \mathrm{t}$ ${\mathrm{C} \mathrm{yr}^{-1}}^{-1}$ for the whole mudflat. Other invertebrates' production amounted to $657.8 \mathrm{t} \mathrm{C} \mathrm{yr}^{1}$ (Table 5). Benthic invertebrate production varied from month to month, and the production to average biomass ratio $(\mathrm{P} / \mathrm{B})$ for the Mai Po mudflat was approximately 3 (McChesney 1997). Three species of mudskippers, i.e. Periophthalmus cantonensis, Boleophthalmus pectinirostris, and Scartelaos viridis, were found on the Mai Po mudflat. The average density was 3.9 ind. $\mathrm{m}^{-2}$ (Chan 1989) and the mean wet weight was assumed to be $8 \mathrm{~g}$ (Young \& Melville 1993). These implied an annual production of $2540.2 \mathrm{t}$, equivalent to $381.0 \mathrm{t} \mathrm{C}$ on the mudflat using the $\mathrm{P} / \mathrm{B}$ ratio of 3 . The total secondary production on the mudflat therefore amounted to $1079.5 \mathrm{t} \mathrm{C} \mathrm{yr}^{-1}$ (crabs + other invertebrates + mudskippers). These mudflat benthos are the base of the food supply for the resident and migrant birds foraging in Deep Bay.

Traditionally, the mudflats in Deep Bay have supported a local fishery harvest of mudskippers and other mangrove-associated fauna, e.g. the mangrove crab Scylla serrata and the large goboid fish Bostrichthys sinensis, but this harvest has declined recently. No detailed work has been done on the amount of mudskippers collected by the fishermen, but Young \&

Table 4. Carbon dynamics in Mai Po gei wais. Carbon exchange in dissolved form is excluded from the calculation. All values are in $\mathrm{t} C \mathrm{yr}^{-1}$. NAPP = net aboveground primary production; NPP = net primary production

\begin{tabular}{|c|c|c|c|c|c|c|}
\hline Source & NAPP(NPP) & $\begin{array}{l}\text { Herbivory } \\
\text { rate }\end{array}$ & Litter & $\begin{array}{l}\text { Storage } \\
\text { in stands }\end{array}$ & $\begin{array}{l}\text { Export to } \\
\text { the ponds }\end{array}$ & $\begin{array}{l}\text { Harvest from } \\
\text { the ponds }\end{array}$ \\
\hline Kandelia candel & 152.1 & 4.9 & 87.5 & 87.2 & 0.3 & \\
\hline Phragmites communis & 353.9 & 0 & 81.3 & 81.3 & 0.1 & \\
\hline Phytoplankton & 6.3 & & & & 6.3 & \\
\hline Algae & 17.9 & & & & 17.9 & \\
\hline Sedimentation & & & & & 988.4 & \\
\hline Prawns & & & & & & 0.8 \\
\hline Fish & & & & & & 1.2 \\
\hline
\end{tabular}


Table 5. Total carbon production on the mudflat and in the water column of Deep Bay, and the allochthonous carbon input into Deep Bay from Shenzhen River, Shan Pui River and the Pearl River estuary. Productivity/availability rates are calculated based on areas of 2700 ha and 11200 ha for the mudflat and the water body, respectively

\begin{tabular}{|c|c|c|}
\hline Source & Total production $\left(\mathrm{t} \mathrm{C}_{\mathrm{yr}}{ }^{-1}\right)$ & Productivity/availability rate (t $\mathrm{C}$ ha ${ }^{-1} \mathrm{yr}^{-1}$ ) \\
\hline \multicolumn{3}{|l|}{ Autochthonous sources } \\
\hline \multicolumn{3}{|l|}{ Autotrophic production } \\
\hline Phytoplankton & 12631.9 & 1.13 \\
\hline Benthic algae & 1462.2 & 0.54 \\
\hline \multicolumn{3}{|c|}{ Heterotrophic production } \\
\hline Crabs & 40.7 & 0.015 \\
\hline Other invertebrates & 657.8 & 0.24 \\
\hline Mudskippers & 381.0 & 0.14 \\
\hline Sub-total & 15173.6 & \\
\hline \multicolumn{3}{|l|}{ Allochthonous sources } \\
\hline Shenzhen River & 9076.7 & 0.81 \\
\hline Shan Pui River & 12715.7 & 1.14 \\
\hline Pearl River estuary & -2065.9 & -0.18 \\
\hline Sub-total & 19726.5 & \\
\hline Total & 34900.1 & \\
\hline
\end{tabular}

Melville (1993) have made a crude estimate. Assuming that mudskipper collection takes place over the months of April to June ( $90 \mathrm{~d}$ ) and there are on average 50 collectors each catching $2.5 \mathrm{~kg} \mathrm{~d}^{-1}$, the annual harvest by fishermen is equal to $11.3 \mathrm{t}(1.7 \mathrm{t} \mathrm{C})$, representing only $0.4 \%$ of the production.

\section{Water body}

Phytoplankton is the main producer in the water column. In the Pearl River Estuary, Huang et al. (1996) reported the annual means of chlorophyll a and primary productivity to be $4.0 \mathrm{\mu g} \mathrm{l}^{-1}$ and $309 \mathrm{mg} \mathrm{C} \mathrm{m}^{-2} \mathrm{~d}^{-1}$. respectively. Assuming that the same values are found in Deep Bay, the annual carbon production in the water column will be $12631.9 \mathrm{t} \mathrm{yr}^{-1}$ (Table 5). It is worth pointing out that the phytoplanktonic biomass in Deep Bay water recorded by some reports $(2.14 \mu \mathrm{g} \mathrm{chl}$ $a^{l^{-1}}$. EPD 1995; $1.40 \mu \mathrm{g} \mathrm{chl} \mathrm{a} \mathrm{l}^{-1}$, Zhang et al. 1987) was lower, and, because the higher turbidity may prohibit phytoplankton production, the above value is likely an overestimate. Apart from the autochthonous carbon sources, Deep Bay receives anthropogenic carbon input from Shenzhen River and Shan Pui River and exchanges POC with the estuary through tidal flushing. Both Shenzhen River and Shan Pui River are heavily polluted, with high $\mathrm{BOD}_{5}$ loading Using the $\mathrm{BOD}_{5}$ data from Peking University (1995) and EPD (1995), the annual TOC discharge was estimated to be 9076.7 and 12715.7 t, respectively, for the Shenzhen River and Shan Pui River (Table 6). A pollution trend and changes in the benthic fauna at different distances away from the river mouth have been documented for both Shenzhen River (McChesney 1997) and Shan Pui River (Chiu 1992, Lee 1995b). Chen et al. (1990) found that the main POC sources in the estuarine water are not from phytoplanktonic production, but from sediment input from the Pearl River, which probably also applies to Deep Bay. The average POC concentration in Deep Bay water was $429.9 \mu \mathrm{g} \mathrm{l}^{-1}$, much higher than that in the estuarine water. This is calculated to be $5.7 \mathrm{t}$

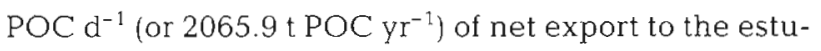
ary via tidal flushing.

\section{Bird utilisation of carbon source}

Based on the curlew's theoretical energy demands for benthic biomass (Melville et al. 1995), a comparison between the required and the available carbon from Deep Bay during a year is presented in Table 7. During the winter season when the curlew population is relatively large (same as most other species), the $\mathrm{S} / \mathrm{R}$ ratio is much lower than 1, reflecting that there is a serious shortage of food from December to February, and that there would be even if all the benthic standing crop biomass were harvestable by the curlew. The potential carbon on the mudflat only contributed on average $47 \%$ of the requirements by curlew. Under the actual conditions, probably only $50 \%$ of the benthic biomass is available. The curlew cannot, therefore, obtain enough food on the mudflats during most of the year (from August to March) and will have to forage elsewhere (Table 7).

According to the published count data for January 1994, 41888 individuals of 74 bird species were 
Table 6. Summary of the carbon sources and sinks in Deep Bay. Total production and import/export values are in $\mathrm{t} C \mathrm{yr}^{-1}$ Productivity/availability rates and import/export rates are in $\mathrm{C} C \mathrm{ha}^{-1} \mathrm{yr}^{-1}$ and are calculated based on areas $270 \mathrm{ha}, 2700 \mathrm{ha}, 200(110$ at Futien and 90 at Mai Po) ha and 11200 ha for the gei wais, the mudflats, the tidal mangroves and the water body, respectively. About $88 \%$ of the production within Deep Bay is available to consumers within the system. +: import into Deep Bay; -: export from Deep Bay

\begin{tabular}{|c|c|c|c|c|}
\hline Habitat & Total production & Import/export & Productivity/availability & Import/export rate \\
\hline Gei Wais & 530.2 & -965.8 & 1.96 & -3.58 \\
\hline Mangroves & 1077.0 & +590.8 & 5.39 & 2.95 \\
\hline Mai Po & 298.6 & +150.5 & 3.32 & 1.67 \\
\hline Futian & 778.3 & +440.3 & 7.08 & 4.00 \\
\hline Mudflats & 2541.7 & +2540.0 & 0.94 & 0.94 \\
\hline Primary & 1462.2 & +1462.2 & 0.54 & 0.54 \\
\hline Secondary & 1079.5 & +1077.8 & 0.40 & 0.40 \\
\hline Water column & 12631.9 & +12631.9 & 1.13 & 1.13 \\
\hline Shenzhen river & 9076.7 & +9076.7 & 0.81 & 0.81 \\
\hline Shan Pui River & 12715.7 & +12715.7 & 1.14 & 1.14 \\
\hline Tidal exchange & & -2065.9 & & -0.18 \\
\hline Total & 38573.2 & +34523.9 & & \\
\hline
\end{tabular}

Table 7 Carbon requirements of a typical wader, the curlew, and carbon supplied by the benthos of the mudflats in Deep Bay. Bird number: count data compiled by G. Carey (unpubl.) from various sources. Carbon required: theoretical required values derived from energy requirements for birds reported in Meire et al. (1994) and Melville et al. (1995). Potential carbon: supposing that the food resources were evenly allocated to all birds, the percentage for curlew was calculated using the curlew's numbers divided by the total bird numbers for the 5 mo reported by the Hong Kong Bird Watching Society (1995); invertebrate biomass carbon was derived from McChesnev (1997); since no value for October was available, the mean of the September and November values was used here. $\mathrm{S} / \mathrm{R}=$ supply to requirement ratio

\begin{tabular}{|lccccccccccccc}
\hline Month: & Jan & Feb & Mar & Apr & May & Jun & Jul & Aug & Sep & Oct & Nov & Dec & Avg \\
\hline Bird number & 450 & 650 & 100 & 10 & 10 & 20 & 20 & 30 & 50 & 75 & 100 & 300 & 151.3 \\
Carbon required $(\mathrm{kg} \mathrm{C)}$ & 863.2 & 1246.8 & 191.8 & 19.2 & 19.2 & 38.4 & 38.4 & 57.6 & 95.9 & 143.9 & 191.8 & 575.5 & 290.1 \\
Potential carbon $(\mathrm{kg} \mathrm{C)}$ & 188.7 & 130.0 & 161.8 & 145.6 & 178.5 & 155.8 & 82.4 & 77.1 & 124.0 & 151.2 & 178.4 & 93.5 & 137.8 \\
S/R & 0.22 & 0.10 & 0.84 & 7.59 & 9.31 & 4.06 & 2.15 & 1.34 & 1.29 & 1.05 & 0.93 & 0.16 & 0.47 \\
S/R (50\% available) & 0.11 & 0.05 & 0.42 & 3.80 & 4.65 & 2.03 & 1.07 & 0.67 & 0.65 & 0.53 & 0.46 & 0.08 & 0.24 \\
\hline
\end{tabular}

recorded in the portion of Deep Bay under Hong Kong jurisdiction. Of these birds, 23 species had a population size greater than 100 , representing $>99 \%$ of the total number of bird individuals in. Deep Bay at that time. The total carbon required by these birds amounted to 40.7 t, with Anas clypeata and Larus ridibundus accounting for about half of the consumption. During January, the carbon production in the mudflat was only $27.8 \mathrm{t}$ (data derived from McChesney 1997); competition for food was probable unless alternative carbon sources were available. Since only a part of the benthic production (equal to the benthic biomass in January 1994) was expected to be harvestable by birds, the maximum carbon supply met only $68.3 \%$ of the birds' needs. This indicates that the Deep Bay mudflats are probably at carrying capacity for wintering shorebirds (Table 8). By supposing that the birds' consumption is just equal to the carbon production on the mudflat and this state represents the sustainable utilisation of food resources, the monthly bird biomass which the mudflat can support, in this ideal case, can be estimated at $11574.6 \mathrm{~kg}$.

\section{DISCUSSION}

\section{Relative importance of natural and anthropogenic carbon sources}

The annual carbon production of Deep Bay totalled $36966 \mathrm{t}$, of which autochthonous autotrophic and heterotrophic sources contributed 14726 (39.8\%) and $1080 \mathrm{t}(2.9 \%)$, respectively (Table 5). Of the autotrophic carbon., vascular plants contributed only $1577 \mathrm{t}$ $(10.7 \%)$ with the remainder $(89.3 \%)$ coming from phytoplankton and benthic algae. Anthropogenic carbon input accounted for $58.0 \%$ of the total, suggesting that the trophodynamics were heavily interfered with 
Table 8. Carbon requirements of bird species foraging on the Deep Bay mudflat in January 1994. A total of 74 species was recorded in this count, but only 23 species with greater than 100 individuals were included in the calculation. They represent over $99 \%$ of the total number of individuals on the mudflat Species count data from the Hong Kong Bird Watching Society (1995). Bird weights are mostly from Guangdong Entomology Institute \& Zhongshan University (1983) and South Chuna Institute of Endangered Animals (1991). These figures are calculated based on the theoretical energy requirement per gram fresh body weight of non-passerines (Aschoff \& Pohl 1970), assuming that bird biomass of all species is the same in the way they consume energy.

BMR: Basal metabolic rate. Carbon required: energy equivalence assumed to be $1 \mathrm{~g} \mathrm{C}=50.28 \mathrm{~kJ}$ (Heymans \& Baird 1995)

\begin{tabular}{|c|c|c|c|c|c|c|}
\hline Species & Number & $\begin{array}{l}\text { Average } \\
\text { weight }(g)\end{array}$ & $\begin{array}{c}\text { BMR } \\
\left(\mathrm{kcal} \mathrm{d}^{-1}\right)\end{array}$ & $\begin{array}{l}3.5 \times \mathrm{BMR}^{-1} \\
\left(\mathrm{kcal} \mathrm{d}^{-1}\right)\end{array}$ & $\begin{array}{l}\text { Total for } \\
\text { population }\end{array}$ & $\begin{array}{c}\text { Carbon required } \\
\left(\mathrm{kg}\left(\mathrm{mo}^{-1}\right)\right.\end{array}$ \\
\hline Numenius arquata & 1005 & 800 & 77.34 & 270.7 & 272043 & 702.1 \\
\hline Egretta garzetta & 452 & 400 & 46.66 & 163.3 & 73816 & 190.7 \\
\hline E. alba & 207 & 875 & 82.56 & 289.0 & 59815 & 154.4 \\
\hline Ardea cinerea & 410 & 1020 & 92.32 & 323.1 & 132479 & 341.9 \\
\hline Tadorna tadorna & 1400 & 1100 & 97.55 & 341.4 & 478002 & 1233.8 \\
\hline Anas penelope & 1282 & 750 & 73.78 & 258.2 & 331051 & 854.7 \\
\hline A. crecca & 1316 & 320 & 39.65 & 138.8 & 182634 & 471.5 \\
\hline A. poecilorhyncha & 148 & 890 & 83.59 & 292.6 & 43300 & 111.9 \\
\hline A. acuta & 1563 & 850 & 80.83 & 282.9 & 434550 & 1121.6 \\
\hline A. clypeata & 6700 & 650 & 66.47 & 232.7 & 1558755 & 4023.8 \\
\hline Ducks & 2190 & $500^{d}$ & 54.90 & 192.2 & 420809 & 1086.2 \\
\hline Recurvirostra avosetta & 770 & 275 & 35.51 & 124.3 & 95703 & 247.1 \\
\hline Charadrius alexandrinus & 3180 & 42 & 9.02 & 31.6 & 100393 & 259.2 \\
\hline C. mongolus & 106 & 58 & 11.42 & 40.0 & 4237 & 10.9 \\
\hline Pluvialis fulva & 220 & 165 & 24.47 & 85.7 & 18843 & 48.7 \\
\hline P. squatarola & 538 & 220 & 30.18 & 105.6 & 56829 & 146.6 \\
\hline Calidris alpina & 2820 & 50 & 10.25 & 35.9 & 101182 & 261.3 \\
\hline Tringa erythropus & 819 & 140 & 21.71 & 76.0 & 62236 & 160.6 \\
\hline T. stagnatilis & 668 & 63 & 12.13 & 42.5 & 28363 & 73.2 \\
\hline T. nebularia & 386 & 150 & 22.83 & 79.9 & 30845 & 79.7 \\
\hline Larus saundersi & 102 & $500^{\mathrm{d}}$ & 54.9 & 192.2 & 19599 & 50.5 \\
\hline L. ridibundus & 15000 & 290 & 36.9 & 129.2 & 1937850 & 5002.2 \\
\hline L. heuglini & 290 & 1050 & 94.29 & 330.0 & 95706 & 247.1 \\
\hline Total & 41888 & & & & 6538994 & 16879.5 \\
\hline
\end{tabular}

by human activities. Carbon loss through harvest (of prawn, fish and mudskippers) from the Deep Bay system was negligible. The net carbon input into Deep Bay was $34523.4 \mathrm{t} \mathrm{yr}^{-1}$, most of which was from phytoplankton and the 2 polluted rivers. Mangrove-derived carbon only contributed $<2 \%$ and seems unlikely to be the main food source for the birds utilising Deep Bay or nearshore consumers.

The hypothesis that coastal wetlands serve as the major supplier of carbon for supporting nearshore secondary consumers (the Outwelling Hypothesis; Odum 1980 ) is still controversial (Dame 1994, Lee 1995a). The magnitude and direction of net material flux are determined by a combination of physical parameters, such as geomorphology, tidal inundation regime and topography, and biotic factors such as the species and growth form of vegetation, seasonal growth patterns and rates of primary production, and the development stages of the marsh-estuarine system (Odum 1969, Dame \& Lefeuvre 1994). It is interesting that in Deep Bay, the outer mangrove is a net exporter of organic carbon while the landward gei wai, a semi-enclosed tidal pond, acts as a net importer. This difference may be caused mainly by the tidal inundation regime. The mangroves are inundated twice a day, but only spring high tides can reach the mangrove stands in the gei wais. The ponds act as sediment traps and accelerate accretion, leading to a progressive increase in elevation of the stands. Less inundated sites allow more litter accumulation to be processed by crabs (Perisesarma spp. and Parasesarma plicata) in the stands, thus leading to little export. This shift from a net exporter to a net importer of organic carbon is probably characteristic of the transition into nutrient-conservative terrestrial systems, a process catalysed by the increased sedimentation rate typical of such impoundments (Lee 1990a).

\section{Capacity for supporting wintering shorebird populations}

Prediction of the actual energy expenditure of birds requires a lot of dedicated effort to clarify the response 
of the species' metabolism to factors such as microhabitat type, temperature regime, wind speed and flocking pattern (e.g. Wiersma \& Piersma 1994) and data on feeding pattern (Pienkowski et al. 1984). Predatory behaviour of shorebirds may also be influenced by many complex processes (Piersma 1987). The calculations on bird utilisation of the Mai Po mudflat carbon resources presented in this paper are, therefore, meant to be only a rough picture. The exact scenario will require clarification of important links, such as the response of the energy demand of various species to changes in environmental conditions.

Koteja (1991) reported the lack of correlation between mass-independent basal and field metabolic rates in birds. A review of the data on intraspecific variations in energy expenditure in small birds also revealed equivocal interspecific patterns for the effect of factors such as body mass, age, temperature and food availability (Bryant \& Tatner 1991). We are also aware that the field to basal metabolic rate ratio may not be constant with body mass (Degen \& Kam 1995). The actual energetic demand of the birds on the Mai Po mudflat is therefore difficult to assess without the availability of field metabolic rates but we believe that the calculation based on basal metabolic rate should still give a reasonable estimate of how well the basic energetic demands of the birds are met by the wetlands. As it is expected that the field metabolic rate of most species is higher than the basal rate, e.g. Pienkowski et al. (1984) and Bryant \& Tatner (1991) suggested, respectively, field rates $2-4$ and $3+$ times higher, the present calculation based on $3.5 \times \mathrm{BMR}$ should represent a realistic estimate of the actual energetic demands of the birds.

The consumption pattern of carbon sources, as demonstrated by the calculation based on the curlew population, generally agrees with the conclusion of McChesney (1997). A predator exclusion experiment conducted by McChesney (1997) on the Mai Po mudflats showed that birds can remove a significant portion ( 48 to $55 \%$ ) of the large bivalves (Macoma sp., Theora sp., Sinonovacula sp.) on the mudflat. Bird predators on the Oosterschelde, SW Netherlands, consumed 30 to $37 \%$ of autumn standing crop biomass (Meire et al. 1994) when the Oosterschelde was thought to be at carrying capacity (Schekkerman et al. 1994). Predation impact (the percentage of invertebrate production taken by birds) on the Mai Po benthic assemblage is much higher than at sites on the East Atlantic Flyway (see Moreira 1997). The picture obtained based on the curlew probably exaggerates the energetic demand of the overall bird assemblage, as the curlew is one of the larger species and Table 7 is constructed assuming equal allocation of resources to bird species by numbers.
Energy requirements of the overall bird assemblage based on $3.5 \times \mathrm{BMR}$ suggest that the Mai Po mudflats are near carrying capacity, i.e. further increases in bird numbers will probably result in significant food competition, decline in body condition, or displacement of the populations to alternative feeding grounds. The requirement amounted to 16.9 t C for January 1994. compared to the production figure of $27.8 \mathrm{t} \mathrm{C}$ for the same month. Bearing in mind that not all of the invertebrates were available to the birds, the Deep Bay mudflats were likely to be near their carrying capacity. One characteristic of this system is that there is considerable storage of production in terms of crab and mudskipper biomass in summer but much larger food demands in winter The crabs and mudskippers grow actively and are available in summer when bird numbers are low. In contrast, these potential food items are generally not available during the winter migratory season. A parallel stury on the trophodynamics of Deep Bay using stable isotopes of carbon and nitrogen suggests that the predominant carbon source for benthic consumers (crabs, prawns and fish) is probably of either anthropogenic or estuarine plankton origin (Lee unpubl.).

Drained-down freshwater fish ponds and gei wais present alternative feeding habitats for the birds in winter. Fish harvesting from these ponds occurs in winter (December to February), when the ponds are drained successively for periods of up to 2-3 wk. Large numbers of birds congregate at the ponds and feed on the high concentration of high-energy food (fish) during this time. This alternative food supply has not been factored into the above calculations (because of the high variability in food availablility and it is a resource outside of the mudflat system) but probably represents an important subsidy to the apparent tight budget for the Deep Bay mudflats.

Many parameters can affect the bird carrying capacity of the Deep Bay mudflat, among which anthropogenic input is a major factor. More than $20000 \mathrm{t}$ pollutant carbon enter Deep Bay per year through wastewater discharge from the 2 main rivers and this has become a major source of carbon budget from the system. Water quality deterioration from the central Mai Po marshes to the Shan Pui River mouth has been recorded (Chiu 1992), and poor quality water has adversely affected the stocking of prawn larvae in the gei wais (Cha et al. 1996). According to the model proposed by Pearson \& Rosenberg (1978), with mild organic pollution, species diversity may increase because of increased food and nutrient availability. With increasing pollution, fundamental changes in community structure occur: (1) a shift from dominance by large, long-lived species to small, opportunistic species and (2) an overall decrease in biomass, species 
diversity and richness. These phenomena have been documented for Shan Pui River (Lee 1995b), Shenzhen River and the mudflats (McChesney 1997). McChesney (1997) recorded the dominance of Capitella spp. in areas around the discharge points of the rivers and the largest common non-air-breathing macrofauna as being the polychaete Dendroneries pinnicirratus $k 15 \mathrm{~cm}$ long). Lee (1995b) argued that species that are airbreathing deposit feeders that are active during low tide, e.g. fiddler crabs, can probably benefit from even gross organic pollution (such as along the Shan Pui River) by avoiding the problems of anaerobiosis and benefiting from the enrichment. Although a livestock waste control ordinance has been enforced since 1991 in Hong Kong, no significant improvement of water quality in Shan Pui River is to date apparent in terms of $\mathrm{BOD}_{5}$ input. As for the Shenzhen River, a joint Shenzhen River Regulation Project has been in progress to improve river quality (Peking University 1995). Nevertheless, it is expected that a collapse of benthic biomass will occur on the mudflat, followed by an exacerbated shortage of food for bird populations, if the present pollution trend is not curtailed. The present situation, however, still seems to be reflective of a biostimulation effect associated with organic enrichment, but future discharges should be closely monitored. What appears to be a major pollution problem from the viewpoint of water quality management is actually a blessing, at least for now, to the conservation value of this mangrove-fringed embayment.

Mudflat habitat loss will reduce the food for birds. This may arise from both mangrove expansion and urban development in the Deep Bay area. The mangrove encroachment rate at Mai Po was estimated to be $3.5 \mathrm{~m} \mathrm{yr}^{-1}$ (Peking University 1995). Based on aerial photographs, Duke $\&$ Khan (in press) obtained an overall encroachment rate of $7.6 \mathrm{~m} \mathrm{yr}^{-1}$. A mudflat loss of $4.9(0.2 \%)$ or $10.6(0.4 \%)$ ha $\mathrm{yr}^{-1}$ has resulted for the mangroves in Deep Bay. Furthermore, the artificial transplanting of Kandelia candel saplings, currently conducted at the Futian Mangrove-Bird Nature Reserve (authors' pers. obs.) to enhance mangrove conservation, may not benefit birds. The infaunal biomass in mangrove stands was lower than on the mudflat (5-15 vs 10-65 g dry wt $\mathrm{m}^{-2}$ ) (McChesney 1997); thus the food resources available will be proportionally reduced for shorebirds. Twenty-eight major development projects around Deep Bay area (Young \& Melville 1993) were identified, 2 of which were the Shenzhen River Regulation Project and the Binhai Causeway in Shenzhen. Habitat loss through the Shenzhen river widening and infilling of ponds will be relatively small and be compensated for by the creation of new wetland habitat at a ratio of 1:1 (Peking University 1995). In contrast, the Binhai Causeway has been designed to cross the north of inner Deep Bay and is likely to involve infilling to the north, resulting in loss of about $20 \%$ of the intertidal area of Deep Bay (McChesney 1997). This will substantialy impact the quantity and the distribution pattern of shorebirds on the mudflat, which may warrant further detailed studies.

Acknowledgements. This work was supported by a postdoctoral fellowship awarded to M.S.L. by the University of Hong Kong. Thanks are due to Prof. B. Morton, Director of the Swire Institute of Marine Science, for providing logistical support to M.S.L. during his stay at the Institute. Mr Steve McChesney and Dr Deborah Cha provided their data for our reference and Dr Lew Young helped with gathering information on bird weights. S.Y.L.'s work on the Mai Po Marshes was supported by grant 295/92M from the Hong Kong Research Grants Council.

\section{LITERATURE CITED}

Anderson C (1994) The production ecology of the mangrove at the Mai Po Marshes Nature Reserve, Hong Kong. PhD thesis, University of Hong Kong

Anderson C, Lee SY (1995) Defoliation of the mangrove Avicennia marina in Hong Kong: cause and consequences. Biotropica 27:218-226

Aschoff J, Pohl H (1970) Der Ruheumsatz von Vögeln als Funktion der Tageszeit und des Körpergrösse. J Ornithol $111: 38-47$

Asjes J, Dankers NMIJA (1994) Variations in tidal exchange processes between a Dutch salt marsh, the Slufter, and the North Sea. In: Mitsch WJ (ed) Global wetlands: old world and new. Elsevier Science BV, Amsterdam, p 201-214

Axelrad DM, Moore KA, Bender ME (1976) Nitrogen, phosphorus and carbon flux in Chesapeake Bay marshes. Virginia Water Research Center, Bulletin 79. Virginia Polytechnical Institute, Blacksburg

Broom MJ, Ng AKM (1996) Water quality in Hong Kong and the influence of the Pearl River. In: Coastal infrastructure development in Hong Kong: a review. Civil Engineering Department, Hong Kong Government, p 193-213

Bryant DM, Tatner P (1991) Intraspecific variation in avian energy expenditure: correlates and constraints. Ibis 133: $236-245$

Cha MW, Young L, Wong KM (1996) The fate of traditional (Gei Wai) prawn farming at the Mai Po Marshes Nature Reserve, Hong Kong. Programme and A.bstracts, AsiaPacific Conference on Science and Management of Coastal Environment, June 25-28. Hong Kong University of Science and Technology. Hong Kong, p 139

Chan KY (1989) The ecology of mudskippers (Pisces: Periophthalmidae) at the Mai Po Marshes Nature Reserve, Hong Kong. MPhil thesis, University of Hong Kong

Chen GZ, Miao SY, Zhong JH (1996) Ecologic study on the mangrove forest in Futian Nature Reserve, Shenzhen, China. Acta Sci Nat Univ Sunyatseni (Suppl) 35:294-300

Chen SY, Zheng ZG, Zheng JL, Lin ZQ (1990) Relationships between suspended particles of organic carbon and environmental factors in Zhujiang Estuary. Trop Oceanol 9: $54-57$

Chiu KT (1992) An assessment of the water pollution status of the Mai Po Marshes Nature Reserve, Hong Kong. PhD thesis, University of Hong Kong 
Crisp DJ (1984) Energy flow measurements. In: Holme NA Mclntyre AD (eds) Methods for the study of marine benthos, 2nd edn. Blackwell Scientific Publications, Oxford, p $284-372$

Cundell AM, Brown MS, Stanford R, Mitchell R (1979) Microbial degradation of Rhizophora mangle leaves immersed in the sea. Estuar Coast Shelf Sci 9:281-286

Dame RF (1994) The net flux of materials between marshestuarine systems and the sea: the Atlantic coast of the United States. In: Mitsh WJ (ed) Global wetlands: old world and new. Elsevier Science BV, Amsterdam. p 295-302

Dame RF, Lefeuvre JC (1994) Tidal exchange: import-export of nutrients and organic matter in New and Old World salt marshes: conclusions. In: Mitsh WJ (ed) Global wetlands: old world and new. Elsevier Science BV, Amsterdam, p 303-305

Degen AA, Kam M (1995) Scaling of field metabolic rate to basal metabolic rate ratio in homeotherms. Ecoscience 2: $48-54$

Duke $N_{1}$ Khan A (in press) Structure and composition of the seaward mangrove forest at the Mai Po Marshes Nature Reserve, Hong Kong. In: Lee SY (cd) Proc Int Workshop on the Mangrove Ecosystem of the Mai Po Marshes and Deep Bay. Hong Kong University Press, Hong Kong

Emmerson WD, McGwynne LE (1992) Feeding and assimilation of mangrove leaves by the crab Sesarma meinerti de Man in relation to leaf-litter production in Mgazana, a warm-temperate southern African mangrove swamp. J Exp Mar Biol Ecol 157:41-53

Environmental Protection Department (1995) Marine water quality in Hong Kong. Hong Kong Government, Hong Kong

Fell JW, Cefalu RC, Master IM, Tallman IM (1975) Microbial activities in the mangrove (Rhizophora mangle) leaf detrital system. In: Walsh GE (ed) Proc Int Symp on Biology and Management of Mangroves. University of Florida, Gainesville, p 661-679

Gong WK. Ong JE (1990) Plant biomass and nutrient flux in a managed mangrove forest in Malaysia. Estuar Coast Shelf Sci 31:519-530

Guangdong Entomology Institute, Zhongshan University (1983) Birds and beasts in Hainan Island. Science Press, Beijing, p 34-277

Han BX, Liu SN, Xu ZC, Li ZS, Li H (1988) Analysis of the hydrological features of Shenzhen Bay. In: Qu GP (ed) Researches on environmental sciences in China. Shanghai Science and Technology Press, Shanghai, p 350-354

Hatcher BG, Johannes RE, Robertson AI (1989) Review of research relevant to conservation of shallow tropical marine ecosystems. Oceanogr Mar Biol Annu Rev 27. $337-414$

Heald EJ (1971) The production of organic detritus in a south Florida Estuary. Sea Grant Technical Bulletin No. 6. University of Miami Sea Grant Program, Coral Gables

Heinle DR, Flemer DA (1976) Flows of materials between poorly flooded tidal marshes and an estuary. Mar Biol 35 : $359-373$

Hemminga MA, Slim FJ, Kazungu J, Ganssen GM, Nieuwenhuize J, Kruyt NM (1994) Carbon outwelling from a mangrove forest with adjacent seagrass beds and coral reefs (Gazi Bay. Kenya). Mar Ecol Prog Ser 106:291-301

Heymans JJ, Baird D (1995) Energy flow in the Kromme estuarine ecosystem, St. Francis Bay, South Africa. Estuar Coast Shelf Sci 41:39-59

Hong Kong Bird Watching Society (1995) Hong Kong bird report. Hong Kong Bird Watching Society, Hong Kong
Hong Kong Bird Watching Society (in press) Hong Kong bird report. Hong Kong Bird Watching Society, Hong Kong

Huang ML, Chen QC, Chen DJ (1996) Plankton composition and environmental status of the Zhujiang Estuary and its coastal waters. Programme and Abstracts. Asia-Pacific Conference on Science and Management of Coastal Environment, June 25-28. Hong Kong University of Science and Technology, Hong Kong, p 171

Irving RTA, Morton B (1988) The geography of Mai Po. World Wide Fund for Nature Hong Kong, Hong Kong

Koteja P (1991) On the relation between basal and field metabolic rates in birds and mammals. Funct Ecol 5:56-64

Kwok (1995) The ecology of two sesarmine crabs, Perisesarma bidens (de Haan) and Parasesarma plicata (Latreille) at the Mai Po Marshes Nature Reserve, Hong Kong. PhD thesis, University of Hong Kong

Lee SY (1989a) Litter production and turnover of the mangrove Kandelia candel (L.) Druce in a Hong Kong tidal shrimp pond. Estuar Coast Shelf Sci 29:75-87

Lee SY (1989b) The importance of Sesarminae crabs Chiromanthes spp. and inundation frequency on mangrove (Kandelia candel (L.) Druce) leaf litter turnover in a Hong Kong tidal shrimp pond. J Exp Mar Biol Ecol 130:23-43

Lee SY (1990a) Primary productivity and particulate organic matter flow in an estuarine mangrove-wetland in Hong Kong. Mar Biol 106:453-463

Lee SY (1990b) Net aerial primary productivity, litter production and decomposition of the reed Phragmites communis in a nature reserve in Hong Kong: management implications. Mar Ecol Prog Ser 66:161-173

Lee SY (1990c) The intensity and consequences of herbivory on the mangrove Kandelia candel (L.) Druce at the Mai Po Marshes, Hong Kong. In: Morton B (ed) The marine flora and fauna of Hong Kong and south China II. Hong Kong University Press, Hong Kong, p 717-725

Lee SY (1991) Herbivory as an ecological process in a Kandelia candel mangal in Hong Kong. J Trop Ecol 7:337-348

Lee SY (1992) The management of traditional tidal ponds for aquaculture and wildifife conservation in southeast Asia: problems and prospects. Biol Conserv 61:113-118

Lee SY (1993) Leaf choice of Sesarminae crabs, Chiromanthes bidens and $C$. maipoensis, in a Hong Kong mangal. In: Morton B (ed) Proc 1st Int Conf on the Marine Biology of the South China Sea. Hong Kong University Press, Hong Kong, p $597-603$

Lee SY (1995a) Mangrove outwelling: a review. Hydrobiologia 295:203-212

Lee SY (1995b) Macrobenthic community structure of a polluted tidal river in Deep Bay, Hong Kong. In: Morton B, Xu G, Zou R, Pan J, Cai G (eds) The marine biology of the South China Sea II. World Publishing Corporation, Beijing, p 43-51

Lee SY (1997) Potential trophic importance of the faecal material of the mangrove sesarmine crab Sesarma messa. Mar Ecol Prog Ser 159:275-284

L1 MS (1993) Research on the mangrove ecosystem in Futian, Shenzhen. PhD thesis, Zhongshan. University, Guangzhou

Li MS (1997) Nutrient dynamics of a mixed mangrove forest in Shenzhen, south China. Estuar Coast Shelf Sci 45:463-472

Li MS, Lee SY (1997) Mangroves of China: a brief review. For Ecol Manage 96:241-259

Li MS, Wong YS, Tam NFY, Lan CY, Chen GZ, Li SH, Chen $X R$ (in press) Litterfall production and return of nutrient elements in Futian mangrove swamp, Shenzhen. In: Lee SY (ed) Proc Int Workshop on the Mangrove Ecosystem of the Mai Po Marshes and Deep Bay. Hong Kong University Press, Hong Kong 
Liu XL, Zhao HT, Zheng DY, Ou XJ, Chen XS (1988) The evolution and development-utilisation of Shenzhen Bay. Trop Oceanol 1:48-56

McChesney S (1997) The benthic invertebrate community of the intertidal mudflat at the Mai Po Marshes Nature Reserve, with special reference to resources for migrant shorebirds. MPhil thesis, University of Hong Kong

Meire PM, Schekkerman H, Meininger PL. (1994) Consumption of benthic invertebrates by waterbirds in the Oosterschelde Estuary, SW Netherlands. Hydrobiologia 282/283: $525-546$

Melville DS, McChesney S, Anderson C, Leader PJ (in press) Predicted impacts of the Shenzhen River regulation project on waterfowl in Deep Bay, Hong Kong. 10th Int Waterfowl Symposium, September 1995, Aveiro, Portugal

Melville DS, Morton B (1983) Mai Po Marshes. World Wildlife Fund Hong Kong, Hong Kong

Moran MA, Wicks RJ, Hodson RE (1991) Export of dissolved organic matter from a mangrove swamp ecosystem: evidence from natural fluorescence, dissolved lignin phenols, and bacterial secondary production. Mar Ecol Prog Ser 76: $175-184$

Moreira F (1997) The importance of shorebirds to energy fluxes in a food web of a south European estuary. Estuar Coast Shelf Sci 44:67-78

Odum EP (1969) The strategy of ecosystem development. Science 164:262-270

Odum EP (1980) The status of three ecosystem-level hypotheses regarding salt marsh estuaries: tidal subsidy, outwelling and detritus-based food chains. In: Kennedy $V$ (ed) Estuarine perspectives. Academic Press, New York, p 485-495

Odum WE (1971) Pathways of energy flow in a south Florida estuary. University of Mrami Sea Grant Bulletin, University of Miami Sea Grant Program, Coral Gables

Odum WE, Fisher JS, Pickral JC (1979) Factors controlling the flux of particulate organic carbon from estuarine wetlands. In: Levington RJ (ed) Ecological processes in coastal and marine systems. Plenum Press, New York, p 69-80

Odum WE, Heald EJ (1972) Trophic analysis of an estuarine mangrove community. Bull Mar Sci 22:671-738

Odum WE, Heald EJ (1975) Mangrove forests and aquatic productivity. In: Hasler AD (ed) Coupling of land and water systems. Springer-Verlag, Berlin, p 129-136

Odum WE, McInvor CC, Smith TJ III (1982) The ecology of the mangroves of south Florida: a community profile. US Fish and Wildlife Service, Office of Biological Services, Washington, DC

Pearson TH, Rosenberg R (1978) Macrobenthic succession in relation to organic enrichment and pollution of the marine environment. Oceanogr Mar Biol Annu Rev 16:229-311

Peking University (1995) Environmental impact assessment study on Shenzhen River Regulation Project: Draft final report. Peking University, Beijing

Pienkowski MW, Ferns PN, Davidson NC, Worrall DH (1984) Balancing the budget: measuring the energy intake and requirements of shorebirds in the field. In: Evans PR, Goss-Custard JD, Hale WG (eds) Coastal waders and waterdowl in winter. Cambridge University Press, Cambridge, p 29-56

Piersma $\mathrm{T}$ (1987) Production by intertidal benthic animals and

Editorial responsibility: Otto Kinne (Editor),

Oldendorf/Luhe, Germany limits to their predation by shorebirds: a heuristic model. Mar Ecol Prog Ser 38:187-196

Rezende CE, Lacerda LD, Ovalle ARC. Silva CAR, Martinelli LA (1990) Nature of POC transport in a mangrove ecosystem: a carbon stable isotope study. Estuar Coast Shelf Sci 30:641-646

Robertson Al (1986) Leaf-burying crabs: their influence on energy flow and export from mixed mangrove forests (Rhtzophora spp.) in north-eastern Australia. J Exp Mar Biol Ecol 102:237-248

Robertson AI, Alongi DM, Boto KG (1992) Food chains and carbon fluxes. In: Robertson AI, Alongi DM (eds) Tropical mangrove ecosystems. American Geophysical Union, Washington, DC, p 293-326

Rodelli MR, Gearing JN, Gering PJ, Marshall N, Sasekumar A (1984) Stable isotope ratio as a tracer of mangrove carbon in Malaysian ecosystems. Oecologia 61:326-333

Royal Observatory, Hong Kong (1995) Monthly weather summary, December 1995. Royal Observatory, Hong Kong

Schekkerman H, Meininger PL, Meire PM (1994) Changes in the waterbird populations of the Oosterschelde Estuary (SW Netherlands) as a result of large-scale coastal engineering works. Hydrobiologia 282/283:509-524

South China Institute of Endangered Animals (1991) A colourful guide to birds in Guangdong Province. Guangdong Science and Technology Press, Guangzhou, p 5-139

Teal JM (1962) Energy flow in the salt marsh ecosystem of Georgia. Ecology 43:614-624

Twilley RR (1985) The exchange of organic carbon in basin mangrove forests in a southwest Florida estuary. Estuar Coast Shelf Sci 20:543-557

Twilley RR, Lugo AE, Patterson-Zucca C (1986) Litter production and turnover in basin mangrove forests in southwest Florida. Ecology 70:670-683

Valiela I (1995) Marine ecological processes, 2nd edn. Springer-Verlag, Berlin

Wiersma P. Piersma T (1994) Effects of microhabitat, flocking, climate and migratory goal on energy expenditure in the annual cycle of red knots. Condor 96:257-279

Woodwell GM, Whitney DE, Hall CAS, Houghton RA (1977) The flax pond ecosystem study: exchanges of carbon in water between a salt marsh and Long Island Sound. Limnol Oceanogr 22:833-838

Xie YM (1989) Research on the water pollution parameters and their correlations. Environ Sci Technol 9:21-29

Yang KY (1996) The feeding ecology of the mudskipper Boleophthalmus pectinirostris (Pisces: Periophthalmidae) at the Mai Po Marshes Nature Reserve, Hong Kong. MPhil thesis, The University of Hong Kong

Young $L$ (1995) The biological importance of Deep Bay and the Mai Po Marshes. In: Chiu ST (ed) Wetlands: Deep Bay and the Mai Po marshes. Instıtute of Biology, Hong Kong, p 16-26

Young L, Melville DS (1993) Conservation of the Deep Bay environment. In: Morton B (ed) The marine biology of the South China sea. Hong Kong University Press, Hong Kong, p 211-231

Zhang JP, Lu SH, Qi YZ (1987) Studies on phytoplankton community structures in Shenzhen Bay and nearby Hong Kong marine area and their relations with red tides. J Jinan Univ (Nat Sci) 3:97-103

Submitted: March 25, 1997; Accepted: July 2, 1998

Proofs received from author(s): September 29, 1998 